\title{
Comparison of oral and intraperitoneal iron supplementation in anaemic rats: a re-evaluation of the mucosal block theory of iron absorption*
}

\author{
Paloma Benito ${ }^{1} \uparrow$, William House ${ }^{2}$ and Dennis Miller $^{3} \ddagger$ \\ ${ }^{1}$ Division of Nutritional Sciences, Cornell University, Ithaca, NY 14853, USA \\ ${ }^{2}$ USDA ARS, US Plant, Soil and Nutrition Laboratory, Ithaca, NY 14853, USA \\ ${ }^{3}$ Department of Food Science, Cornell University, Ithaca, NY 14853, USA
}

(Received 9 May 1997 - Revised 12 December 1997 - Accepted 26 January 1998)

\begin{abstract}
To evaluate the extent to which daily oral Fe supplements may block Fe absorption from a subsequent dose, we compared effects of oral and intraperitoneal (i.p.) Fe supplementation on $\mathrm{Fe}$ status in anaemic rats (haemoglobin ( $\mathrm{Hb}$ ) $90 \mathrm{~g} / \mathrm{l}$ ). A ligated duodenal loop technique was used to assess the effects of the $\mathrm{Fe}$ supplements administered either orally or i.p. at different frequencies on Fe absorption from a subsequent test dose. Anaemic Sprague-Dawley rats were assigned to seven groups of eight rats each and received either oral or i.p. Fe supplements for $3 \mathrm{~d}$ as follows: (1) $4 \mathrm{mg}$ oral supplement daily (three doses in $3 \mathrm{~d}$ ); (2) $4 \mathrm{mg}$ oral supplement once (one dose on day 1, low-Fe dose on days 2 and 3); (3) $12 \mathrm{mg}$ oral supplement once (one dose on day 1, low-Fe dose on days 2 and 3); (4) $3.2 \mathrm{mg}$ i.p. supplement daily (three doses in $3 \mathrm{~d}$ ); (5) $3.2 \mathrm{mg}$ i.p. supplement once (one dose on day 1); (6) $9.6 \mathrm{mg}$ i.p. supplement once (one dose on day 1); (7) low-Fe diet (control). The effectiveness of the supplements in treating Fe deficiency on each of the two test-factors, i.e. route of administration and frequency of dose, was assessed by determining $\mathrm{Hb}-\mathrm{Fe}$ gain and liver-Fe stores after the $3 \mathrm{~d}$ test period. Oral supplementation was as effective as i.p. in improving the $\mathrm{Fe}$ status of the anaemic animals. However, a $15 \mathrm{~min}$ absorption of a radio-Fe test dose from a ligated loop in i.p.-supplemented groups was significantly higher (11.68 (SD 1.70) \%, 17.49 (SD 4.59) \%, 16.71 (SD 3.39) \%) than in orally supplemented groups (3.24 (SD 1.35) \%, 2.45 (SD 1.05) \%, 1.80 (SD 0.35) \%) despite equal body Fe stores. No significant difference in intestinal Fe absorption efficiency was detected within the oral groups but those supplemented only once were more effective than or as effective as the group receiving daily supplements for $3 \mathrm{~d}$ in improving $\mathrm{Fe}$ status as indicated by $\mathrm{Hb}$ regeneration efficiency. We conclude that there is a mucosal block with the administration of oral Fe supplements but the extent of this blocking effect during oral Fe supplementation is not as dramatic as currently thought in the context of the poor efficacy of daily Fe supplementation programmes.
\end{abstract}

Iron: Anaemia: Intestine: Mucosal block

Many studies using a single dose of Fe have provided evidence of diminished Fe absorption after the consumption of a large Fe dose (Hahn et al. 1943; Brown et al. 1958; Solomons et al. 1983; O'Neil-Cutting \& Crosby, 1987). Brown et al. (1958) found that a large dose, i.e. $2-$ $4 \mathrm{mg}$ of $\mathrm{Fe} / \mathrm{kg}$ body weight, resulted in decreased absorption of the subsequent radio-Fe tracer. This effect lasted about $6 \mathrm{~h}$ in Fe-replete subjects and up to $3 \mathrm{~h}$ in patients with Fe-deficiency anaemia. O'Neil-Cutting \& Crosby (1987) also found that administering a large Fe dose inhibited absorption of $\mathrm{Fe}$ administered subsequently and the effect lasted $24 \mathrm{~h}$. However, it is not well understood when, and to what extent, these changes in Fe absorption occur during $\mathrm{Fe}$ therapy. The extent of the so-called 'blocking effect' and its implications on the treatment of Fe deficiency are not clear.

\footnotetext{
Abbreviations: $\mathrm{Hb}$, haemoglobin; HRE, haemoglobin regeneration efficiency; i.p., intraperitoneal; NTA, nitrilotriacetate complex.

* Mention of a trademark on a proprietary product does not constitute a guarantee or warranty of the product by the USDA and does not imply its approval to the exclusion of other products that might be suitable.

$\nmid$ Corresponding author: Dr Paloma Benito, present address: USDA, ARS, Western Human Nutrition Research Center, PO Box 29997, San Francisco, CA 94129, USA; fax +14155561432 , email pbenito@whnrc.usda.gov

$\ddagger$ For reprints.
} 
Similarly, the mechanism behind the blocking effect is unknown. On the one hand, intestinal mucosal $\mathrm{Fe}$ concentration is believed to play a role in $\mathrm{Fe}$ absorption (Conrad \& Crosby, 1963). It is assumed that the blocking effect during daily $\mathrm{Fe}$ supplementation occurs as a consequence of the loading of the cells with Fe from the previous supplemental dose, which in turn causes a lower absorption of the next dose. On the other hand, $\mathrm{Fe}$ absorption is affected by body $\mathrm{Fe}$ stores. Rebuilding storage Fe during the treatment of Fe deficiency is a slow process because $\mathrm{Fe}$ absorption is inversely proportional to Fe status. Norrby \& Sölvell (1974) found that Fe absorption from supplemental $\mathrm{Fe}$ in Fe-deficient patients was directly related to the degree of $\mathrm{Fe}$ deficiency; Fe absorption in three successive $10 \mathrm{~d}$ periods was shown to decrease as $\mathrm{Fe}$ repletion occurred.

According to Crosby's (1963) hypothesis, in states of Fe deficiency when little storage Fe exists in the body, the transport of Fe from the gastrointestinal tract through the mucosal cells into the body would be fast and efficient. However, data from recent studies showing that intermittent Fe supplementation is more efficient than or as efficient as daily supplementation (Schultink et al. 1995; Viteri et al. 1995; Viteri, 1996) suggest that there is a pronounced blocking effect even in anaemic individuals with the administration of daily Fe supplements.

In view of the many trials now underway in developing countries to test the efficacy of change from daily to weekly Fe supplementation, we conducted this study to understand better the blocking effect in the context of Fe deficiency and supplementation therapy. The purpose of this study was two-fold: (1) to re-evaluate the concept of the blocking effect in the context of Fe deficiency and supplementation therapy, and (2) to examine whether the blocking effect is indeed explained by $\mathrm{Fe}$ levels in the mucosal cells independent of body Fe stores. Specifically, we studied the effect of a $3 \mathrm{~d}$ Fe supplementation period, both orally and intraperitoneally (i.p.), on $\mathrm{Fe}$ absorption from a subsequent test dose.

\section{Materials and methods}

\section{Animals and diets}

Fifty-six Sprague-Dawley male weanling rats (Camm Research Lab Animals, Wayne, NJ, USA) were individually housed in stainless steel cages with mesh bottoms in a temperature-controlled room $\left(20-22^{\circ}\right)$ on a $12 \mathrm{~h}$ dark-light cycle. Animal care procedures and experimental protocols were approved by the Cornell University Institutional Animal Care and Use Committee.

The rats initially weighed about $70 \mathrm{~g}$ each and had free access to a low-Fe diet for the first $4 \mathrm{~d}$. They were then trained to meal-feed as described previously (Benito et al. 1997). Two meals were offered daily: one at 06.00 and one at 18.00 hours. Development of anaemia was monitored by measuring haemoglobin $(\mathrm{Hb})$ concentrations in six randomly selected animals. Blood samples were collected as described previously (Benito et al. 1997). Mild anaemia $(90 \mathrm{~g} \mathrm{Hb} / 1)$ became apparent after the rats were fed on the low-Fe diet for $12 \mathrm{~d}$. Subsequently, $\mathrm{Hb}$ concentrations were determined in all animals and the rats were assigned to treatment groups.

After the groups were formed, animals in oral groups received $1.0 \mathrm{~g}$ of premeal before the morning meal at 06.00 hours. The premeal consisted of low-Fe diet and sucrose $(50: 50, \mathrm{w} / \mathrm{w})$ to which the Fe supplement was added. Rats in i.p. groups received $\mathrm{Fe}$ injections before a premeal that consisted of the low-Fe diet and sucrose only. The groups given one dose in $3 \mathrm{~d}$ received the Fe-deficient diet on the $2 \mathrm{~d}$ after administration of the Fe supplement.

A low-Fe diet was purchased (ICN Biomedicals Inc., Cleveland, $\mathrm{OH}, \mathrm{USA}$ ). It was manufactured according to the specifications of the AIN-76 diet (Bieri et al. 1977; Bieri, 1980) but without ferric citrate. By analysis, the diet contained 7.9 (SD 0.5, n 3) $\mathrm{mg} \mathrm{Fe} / \mathrm{kg}$ diet.

\section{Supplements and ${ }^{59} \mathrm{Fe}$ test dose}

The oral supplements contained either 4 or $12 \mathrm{mg}$ of elemental $\mathrm{Fe}$ as reagent-grade $\mathrm{FeSO}_{4} \cdot \mathrm{H}_{2} \mathrm{O}$ (Fortitech Inc., Schenectady, NY, USA). The i.p. supplements consisted of Fe-dextran as stock solution of $100 \mathrm{mg} / \mathrm{ml}$ (Butler Company, Columbus, OH, USA) diluted to the appropriate concentration with sterile physiological saline solution $(9 \mathrm{~g}$ $\mathrm{NaCl} / \mathrm{l}$ ).

A solution containing $\mathrm{Fe}$ and ${ }^{59} \mathrm{Fe}$-labelled ferric nitrilotriacetate complex (NTA) molar ratio 1:5 was prepared fresh daily. The test dose was $0.5 \mathrm{ml}$ of the $\mathrm{Fe}$ solution containing $1.85 \times 10^{-4} \mu \mathrm{Bq}$ of ${ }^{59} \mathrm{Fe}$ and $50 \mu \mathrm{g}$ of total $\mathrm{Fe}$. The ${ }^{59} \mathrm{Fe}$ was obtained as $\mathrm{FeCl}_{3}$ (DuPont Biotechnology Division, Wilmington, DE, USA) and the stock non-labelled Fe was that of an atomic absorption standard solution (Sigma Chemical Company, St. Louis, MO, USA).

\section{Experimental design}

Supplemental Fe was administered either orally or i.p. to Fe-depleted $(90 \mathrm{~g} \mathrm{Hb} / \mathrm{l})$ rats. The rats received the $\mathrm{Fe}$ supplement either once or three times on three consecutive days. Rats were allotted by $\mathrm{Hb}$ concentration to groups of eight rats each. Each group was then assigned randomly to one of seven treatments (Table 1).

The i.p. Fe doses contained $80 \%$ of the amount of Fe in the oral doses in order to adjust for efficiency of intestinal absorption of Fe. Each treatment group consisted of eight animals. Terminal surgery was conducted on fourteen rats

Table 1. Route of frequency and administration of Fe supplements provided to anaemic rats

\begin{tabular}{lccc}
\hline Group & Route & Fe (mg/dose) & Frequency \\
\hline 1 & Oral & 4 & Daily for three days $^{*}$ \\
2 & Oral & 4 & Once $^{\star}$ \\
3 & Oral & 12 & Once $^{\star}$ \\
4 & Intraperitoneal & $3 \cdot 2$ & Daily for three days \\
5 & Intraperitoneal & $3 \cdot 2$ & Once $^{*}$ \\
6 & Intraperitoneal & $9 \cdot 6$ & Once $^{*}$ \\
$7+$ & None & None & None \\
\hline
\end{tabular}

* Iron supplement given on day 1 and low-Fe diet plus sucrose on days 2 and 3 . $\dagger$ Group 7 served as the non-supplemented control. 
on each of four successive days. Each surgical group consisted of two animals from each of the seven treatment groups. Rats in the surgical groups were selected on the basis of body weight so that the largest, i.e. heaviest, animals were chosen for surgery first. This arrangement allowed smaller animals extra time to grow so that their body weights on their respective surgery days would be roughly equal to those who preceded them. The order in which animals were selected for surgery on each day was randomized and the supplementation for each batch was staggered to synchronize with the surgery schedule.

\section{Ligated duodenal segment procedure (surgery)}

Animals were anaesthetized with a $2: 1(\mathrm{v} / \mathrm{v})$ mixture of ketamine hydrochloride (Ketaset ${ }^{\mathbb{\mathbb { R }}}$, Henry Schein Inc., Port Washington, NY, USA) and xylazine (Rompun ${ }^{\circledR}$, Henry Schein Inc., Port Washington, NY, USA). The abdomen was opened by a $30-40 \mathrm{~mm}$ midline incision and a $100 \mathrm{~mm}$ segment of the small intestine was ligated. A ligature (Ligapak 3-0, Ethicon Inc., Somerville, NJ, USA) was loosely tied around the small intestine at the pyloric valve. A second ligature was firmly tied approximately $100 \mathrm{~mm}$ posterior to the first. A needle (25G, $160 \mathrm{~mm}(0.625 \mathrm{in})$ ) was inserted into the lumen of the duodenal segment under the loosely tied ligature which was then tightened before the injection of $0.5 \mathrm{ml}$ of the Fe test dose.

After the injection, the needle was withdrawn, the incision was closed and covered with saline-soaked cotton gauze, and the rat was kept warm under the heat of a lamp. After $15 \mathrm{~min}$, the anaesthetized animal was assayed in a whole-body gamma-scintillation spectrometer to determine the initial ${ }^{59} \mathrm{Fe}$ activity. Then the animal was killed by $\mathrm{CO}_{2}$ overexposure, the duodenal segment immediately removed, and the carcass assayed for ${ }^{59} \mathrm{Fe}$ activity. The duodenal segment was placed on a chilled glass plate after removal of adherent tissue. The tied duodenal segment was cut open by snipping off the ends of the segment close to the ligature and the lumen contents were flushed into a vial with a syringe containing $12 \mathrm{ml}$ ice-cold $\mathrm{Ca}$ - and $\mathrm{Mg}$-free Hanks' balanced salt solution buffered with $0.005 \mathrm{M}$-Tris- $\mathrm{HCl}$ at pH 7.4 (Life Technologies Inc., GIBCO, Grand Island, NY, USA).

Fe absorption was determined by expressing the ${ }^{59} \mathrm{Fe}$ in the carcass as a percentage of the initial ${ }^{59} \mathrm{Fe}$ activity.
Blood samples were collected by heart-puncture phlebotomy for final $\mathrm{Hb}$ determinations. Livers were removed and placed in counting vials.

\section{Preparation of mucosal cells and ferritin determination}

Isolation of mucosal cells from the segment was done by mechanical vibration (Momtazi \& Herbert, 1973; Savin \& Cook, 1978; Whittaker et al. 1989) as described previously (Benito et al. 1997). Mucosal cell ferritin was measured by an immunoassay kit (Spectro Rat Ferritin, Ramco Laboratories, Houston, TX, USA). Protein concentration in the epithelial cell suspension was measured with a protein assay kit using serum albumin as a standard (Bio-Rad Laboratories, Life Science Group, Richmond, CA, USA).

\section{Iron status parameters}

Liver non-haem $\mathrm{Fe}$ was measured by the method of Torrance \& Bothwell (1968) and $\mathrm{Hb}$ concentrations were determined by the cyanomethaemoglobin method (National Committee for Clinical Laboratory Standards, 1984).

$$
{ }^{59} \mathrm{Fe} \text { analyses }
$$

Carcasses were assayed for ${ }^{59} \mathrm{Fe}$ in a small animal wholebody gamma-scintillation spectrometer as described by Welch \& House (1980). Luminal contents, rinsings, and other samples were analysed for ${ }^{59} \mathrm{Fe}$ in an automatic gamma-counter (Auto-Gamma model 5530, Packard Instruments, Downers Grove, IL, USA). Appropriate standards and blanks were prepared. The ${ }^{59} \mathrm{Fe}$ data were corrected for isotopic decay and differences in the counting efficiency of the two counters.

\section{Statistical analyses}

Data are reported as means with standard errors. They were analysed according to randomized block design for twoway ANOVA using Minitab (Statistical Software Release 10, Minitab Inc., State College, PA, USA). Following a significant $F$ test $(P<0.05)$, Tukey's test was used to determine significant differences between means (Snedecor \& Cochran, 1989).

Table 2. Weight gain and haemoglobin concentrations of rats fed on iron supplements for three days (Values are means with standard errors for six to eight rats per group)

\begin{tabular}{|c|c|c|c|c|c|c|c|c|}
\hline \multirow[b]{2}{*}{ Group } & \multirow[b]{2}{*}{ Treatment } & \multirow[b]{2}{*}{ Regimen number } & \multicolumn{2}{|c|}{ Weight gain $(\mathrm{g})$} & \multicolumn{4}{|c|}{$\mathrm{Hb}$ concentration $(g /)$} \\
\hline & & & Mean & SE & Initial & SE & Final & $\mathrm{SE}$ \\
\hline $\begin{array}{l}1 \\
2 \\
3 \\
4 \\
5 \\
6 \\
7\end{array}$ & $\begin{array}{c}4 \mathrm{mg} \text { oral daily } \\
4 \mathrm{mg} \text { oral once } \\
12 \mathrm{mg} \text { oral once } \\
3.2 \mathrm{mg} \text { i.p. daily } \\
3.2 \mathrm{mg} \text { i.p. once } \\
9.6 \mathrm{mg} \text { i.p. once } \\
\text { Control }\end{array}$ & $\begin{array}{l}1 \\
2 \\
3 \\
1 \\
2 \\
3 \\
4\end{array}$ & $\begin{array}{l}31^{\mathrm{a}} \\
33^{\mathrm{a}} \\
26^{\mathrm{a}} \\
33^{\mathrm{a}} \\
30^{\mathrm{a}} \\
33^{\mathrm{a}} \\
28^{\mathrm{a}}\end{array}$ & $\begin{array}{l}3.2 \\
2.6 \\
2.8 \\
3.4 \\
3.5 \\
2.4 \\
1.8\end{array}$ & $\begin{array}{l}90 \cdot 5^{a} \\
92 \cdot 1^{a} \\
90 \cdot 3^{a} \\
91 \cdot 1^{a} \\
90 \cdot 4^{a} \\
89 \cdot 9^{a} \\
93 \cdot 6^{a}\end{array}$ & $\begin{array}{l}3.9 \\
3.8 \\
3.9 \\
3.2 \\
3.3 \\
4.0 \\
5.1\end{array}$ & $\begin{array}{c}122 \cdot 2^{\mathrm{a}} \\
107 \cdot 7^{\mathrm{ab}} \\
132 \cdot 2^{\mathrm{a}} \\
125 \cdot 6^{\mathrm{a}} \\
98 \cdot 2^{\mathrm{ab}} \\
124.8^{\mathrm{a}} \\
79.8^{\mathrm{b}}\end{array}$ & $\begin{array}{r}6.4 \\
6.5 \\
5.3 \\
11.0 \\
10.3 \\
4.5 \\
7.7\end{array}$ \\
\hline
\end{tabular}

i.p., intraperitoneal.

Values within a column not sharing a common superscript are statistically different $(P<0.05)$. 

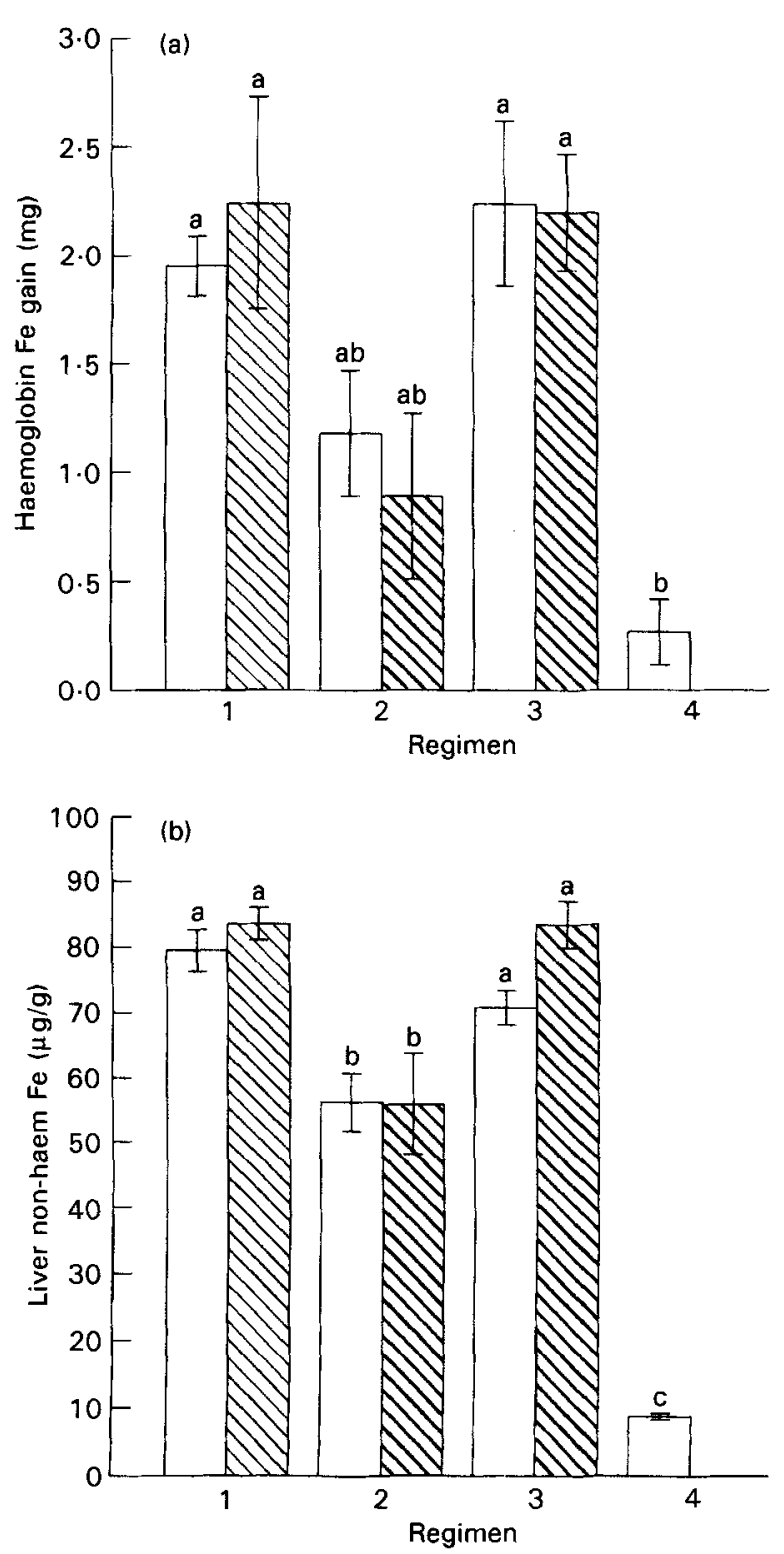

Fig. 1. Haemoglobin Fe gain (a) and liver non-haem $\mathrm{Fe}$ (b) of rats fed Fe supplements for 3 days. Regimen $1,4 \mathrm{mg}$ oral or $3.2 \mathrm{mg}$ i.p. daily; regimen $2,4 \mathrm{mg}$ oral or $3.2 \mathrm{mg}$ i.p. once; regimen $3,12 \mathrm{mg}$ oral or $9.6 \mathrm{mg}$ i.p. once; regimen 4, low-Fe diet (control). Bars are means with standard error $(n 6-8)$. Oral administration of Fe supplement $(\square)$; i.p. administration of Fe supplement (\$). Bar values not sharing a common letter of the alphabet are significantly different $(P<0.05)$.

\section{Results}

\section{Effect of supplementation on body iron status and growth}

Table 2 shows body weight gain and initial and final $\mathrm{Hb}$ concentrations. All animals grew well. Fe supplementation did not affect body weight gain. Except in those rats given a single $\mathrm{Fe}$ dose ( $4 \mathrm{mg}$ oral, $3.2 \mathrm{mg}$ i.p.), $\mathrm{Hb}$ values attained normal levels after the $3 \mathrm{~d}$ supplementation period.

Total body $\mathrm{Hb}-\mathrm{Fe}$ was calculated at the beginning and end of supplementation in order to express results as $\mathrm{Hb}-\mathrm{Fe}$ gain, a more precise indicator that also accounts for differences in body weight. Route of administration of the
Fe supplement did not affect $\mathrm{Hb}-\mathrm{Fe}$ gain or liver Fe stores (Fig. 1).

$\mathrm{Hb}$ regeneration efficiency (HRE; $\mathrm{Hb}$ gain/Fe intake) averaged 16 (4 $\mathrm{mg}$ daily), 30 (4 $\mathrm{mg}$ once), and 19 (12 mg once) $\%$ for the oral groups, and 23 ( $3.2 \mathrm{mg}$ daily), 28 ( $3.2 \mathrm{mg}$ once), and 23 ( $9.6 \mathrm{mg}$ once) $\%$ for the i.p. groups. It should be noted that HRE of the group receiving a single oral dose ( $4 \mathrm{mg}$ ) was remarkably higher than that of three daily oral doses of $4 \mathrm{mg}(30 v .16 \%)$ and that although a greater proportion of $\mathrm{Fe}$ is generally absorbed with a smaller dose (Hahn et al. 1951), we observed in the oral groups, that a single dose of $12 \mathrm{mg}$ was as effective in improving the $\mathrm{Fe}$ status of the animals as three daily doses of $4 \mathrm{mg}$ each (Table 2).

Fe repletion, in terms of liver non-haem Fe, followed a similar pattern. Hb-Fe gain was significantly correlated with liver Fe values $(r$ 0.724, $P<0.001)$.

\section{Effect of supplementation on absorption efficiency via ligated loops}

Since Fe absorption is affected by many factors including quantity of dose (Hahn et al. 1951), we also evaluated the efficiency of mucosal cells to absorb $\mathrm{Fe}$ after exposing them to supplemental $\mathrm{Fe}$ via either the oral or i.p. route. Thus, we use 'absorption efficiency' to mean mucosal cell Fe absorption efficiency independent of dose quantity.

We encountered some problems involving anaesthesia during the ligated-loop procedure. A few animals died from anaesthetic overdose. Since all missing observations came from the first $2 \mathrm{~d}$ (surgical groups 1 and 2), the data presented here only correspond to four animals per treatment group, i.e. two rats per surgery on each of the last $2 \mathrm{~d}$.

Table 3 shows the distribution of ${ }^{59} \mathrm{Fe}$ from the test dose after a $15 \mathrm{~min}$ absorption period. Data are expressed as percentages of the total amount of isotope administered to the animal. The length of the ligated duodenal segment was similar for all animals with an average of $90 \mathrm{~mm}$.

Fe absorption was greater in groups supplemented by i.p. injection than in groups supplemented orally. The control group differed significantly from groups receiving oral supplements but not from i.p. groups. No significant difference in absorption efficiency was detected within the oral or i.p. groups.

\section{Effect of supplementation regimens on duodenal mucosal ferritin}

Table 4 shows ferritin concentrations in the mucosal cells. Effects of frequency of dose $(P<0.001)$, route through which the dose was administered $(P=0.002)$, and the interaction between frequency and route $(P<0.001)$ were significant. As indicated by ferritin concentration, multiple doses of the oral Fe supplement caused Fe loading of the cells while single-doses resulted in much lower ferritin values. Synthesis of ferritin in the mucosal cells was affected by the route of administration depending on the frequency of the Fe dose. Oral Fe supplements produced more ferritin when the doses were administered daily. In 
Table 3. Distribution of iron test dose ${ }^{\star}$ after $15 \mathrm{~min}$ absorption period in rats receiving oral or intraperitoneal iron supplements (Values are means with standard errors for four rats per group)

\begin{tabular}{|c|c|c|c|c|c|c|c|}
\hline \multirow[b]{3}{*}{ Treatment } & \multirow[b]{3}{*}{ Regimen number } & & & \multicolumn{4}{|c|}{ Percentage of initial ${ }^{59} \mathrm{Fe}$ test dose } \\
\hline & & \multicolumn{2}{|c|}{ Carcass } & \multicolumn{2}{|c|}{ Contents plus rinsings } & \multicolumn{2}{|c|}{ Rinsed segment } \\
\hline & & Mean & SE & Mean & SE & Mean & $\mathrm{SE}$ \\
\hline $\begin{array}{l}4 \mathrm{mg} \text { oral daily } \\
4 \mathrm{mg} \text { oral once } \\
12 \mathrm{mg} \text { oral once } \\
3.2 \mathrm{mg} \text { i.p. daily } \\
3.2 \mathrm{mg} \text { i.p. once } \\
9.6 \mathrm{mg} \text { i.p. once } \\
\text { Control }\end{array}$ & $\begin{array}{l}1 \\
2 \\
3 \\
1 \\
2 \\
3 \\
4\end{array}$ & $\begin{array}{c}3 \cdot 2^{\mathrm{a}} \\
2 \cdot 4^{\mathrm{a}} \\
1 \cdot 8^{\mathrm{a}} \\
11 \cdot 7^{\mathrm{b}} \\
17 \cdot 5^{\mathrm{b}} \\
16 \cdot 7^{\mathrm{b}} \\
11 \cdot 5^{\mathrm{b}}\end{array}$ & $\begin{array}{l}1.3 \\
1.0 \\
0.3 \\
1.7 \\
4.6 \\
3.4 \\
0.6\end{array}$ & $\begin{array}{l}78.9 \\
83.2 \\
84.8 \\
74.0 \\
70.3 \\
66 \cdot 0 \\
73.7\end{array}$ & $\begin{array}{l}7.8 \\
4.0 \\
5.8 \\
3.3 \\
3.9 \\
7.0 \\
2.9\end{array}$ & $\begin{array}{l}17.9 \\
14 \cdot 3 \\
13.4 \\
14.3 \\
12.2 \\
17.3 \\
14.7\end{array}$ & $\begin{array}{l}8.6 \\
5.0 \\
6.1 \\
2.9 \\
0.8 \\
3.9 \\
2.4\end{array}$ \\
\hline $\begin{array}{l}\text { Model } \\
\text { Frequency } \\
\text { Administration }\end{array}$ & & $\begin{array}{c}\text { NS } \\
0.000\end{array}$ & & $\begin{array}{c}\text { ANOVA } \\
\text { NS } \\
0.014\end{array}$ & & $\begin{array}{l}\text { NS } \\
\text { NS }\end{array}$ & \\
\hline
\end{tabular}

NS, not significant $(P>0.05)$; i.p., intraperitoneal.

a,b Values within a column not sharing a common superscript are statistically different $(P<0.05)$.

* Dose contained $50 \mu \mathrm{g}$ of ${ }^{59} \mathrm{Fe}^{3+}$ (NTA) $)_{5}$.

Table 4. Mucosal ferritin of rats fed iron supplements

(Values are means with standard errors for six rats per group)

\begin{tabular}{lcccc}
\hline & & & \multicolumn{2}{c}{ Ferritin (ng/mg protein) } \\
\cline { 3 - 5 } Group & Treatment & Regimen number & Mean & SE \\
\hline 1 & $4 \mathrm{mg}$ oral daily & 1 & $90.0^{\mathrm{a}}$ & 7.5 \\
2 & $4 \mathrm{mg}$ oral once & 2 & $31.6^{\text {bd }}$ & 4.1 \\
3 & $12 \mathrm{mg}$ oral once & 3 & $41.3^{\mathrm{bc}}$ & 5.0 \\
4 & $3.2 \mathrm{mg}$ i.p. daily & 1 & $30.1^{\text {bd }}$ & 4.1 \\
5 & $3.2 \mathrm{mg}$ i.p. once & 2 & $27.9^{\text {bd }}$ & 3.9 \\
6 & $9.6 \mathrm{mg}$ i.p. once & 3 & $58.7^{\mathrm{c}}$ & 7.1 \\
7 & Control & 4 & $17.1^{\mathrm{d}}$ & 2.6 \\
\hline
\end{tabular}

i.p., intraperitoneal.
a,b,c,d Values within a column not sharing a common superscript are statistically different $(P<0.05)$.

contrast, i.p. supplements caused more ferritin to be synthesized in mucosal cells when administered in a single dose than in multiple doses.

\section{Discussion}

The term 'mucosal block' was first proposed by Hahn et al. (1943) to describe a diminished avidity for Fe of the intestinal mucosa following an orally administered Fe dose. A few years later, Granick (1946) proposed that mucosal ferritin would serve as a block to the absorption of excess Fe. This concept was based on the belief that Fe taken up by the mucosa is incorporated into mucosal ferritin and the Fe in the ferritin enters the bloodstream only as needed. However, later studies (Conrad \& Crosby, 1963; Crosby, 1963; Wheby \& Crosby, 1963) showed that most absorbed $\mathrm{Fe}$ is actually transferred across the mucosa directly to the plasma rather than passing through the mucosal ferritin pool and that $\mathrm{Fe}$ would be absorbed directly unless it is sequestered by mucosal ferritin whose synthesis is related to the level of body Fe stores. Thus, according to Crosby's hypothesis (1963), little mucosal ferritin is produced in the state of Fe deficiency and the transport of Fe from the gastrointestinal tract through the mucosal cells into the body is fast and nearly complete. However, Crosby's hypothesis (1963) and the role of ferritin as a regulator of $\mathrm{Fe}$ absorption were later challenged by other investigators (Brittin \& Raval, 1970, 1971) who found that Fe-deficient animals retained the capacity to synthesize mucosal ferritin in response to small doses of oral Fe. To date, the role of mucosal ferritin in Fe absorption remains controversial.

In this study we examined the extent to which any $\mathrm{Fe}$ remaining in the cells during oral treatment inhibits subsequent $\mathrm{Fe}$ absorption. Specifically, we evaluated the extent and nature of the blocking effect during the treatment of Fe deficiency in two ways: (1) by comparing oral $v$. i.p. Fe supplementation, and (2) by comparing daily supplements $v$. a single dose designed to match mucosal cell turnover. We found that oral supplementation was as effective as i.p. injection in improving the Fe status of the anaemic animals. An earlier study in humans also reported no significant difference in the haematological response of severely Fe-deficient patients to orally administered $\mathrm{FeSO}_{4}$ and i.p. Fe-dextran complex (McCurdy, 1965). Our finding 
suggests that the blocking effect in oral supplementation does not have a great impact on the recovery of anaemic animals. It also shows that the estimated $80 \%$ absorption that we used as a correction factor for oral v. i.p. administration is consistent with previous results in the literature (Pritchard, 1961).

Intestinal absorption of a test dose, however, was higher in groups that received supplemental $\mathrm{Fe}$ by i.p. injection suggesting some kind of absorption block after exposure to oral Fe. Fe stores were equally repleted in the oral and i.p. groups, thus they cannot account for the higher absorption efficiency of the test dose in the i.p. groups. Nevertheless, as stated earlier, both oral and i.p. administrations resulted in an equal rate of recovery in terms of $\mathrm{Fe}$ status, i.e. $\mathrm{Hb}$ gain and liver $\mathrm{Fe}$. The above-mentioned data suggest that differences in $\mathrm{Fe}$ absorption may exist when measured from a single labelled $\mathrm{Fe}$ test dose (Fe solution without food) or when estimated from values of $\mathrm{Fe}$ status.

When comparing daily supplements $v$. a single dose designed to match mucosal cell turnover we found that a single dose of $12 \mathrm{mg}$ was as effective in improving the $\mathrm{Fe}$ status of the anaemic animals as three daily doses of $4 \mathrm{mg}$ each, even when it is known that a greater proportion of $\mathrm{Fe}$ is generally absorbed with a smaller dose (Hahn et al. 1951). Although the single oral dose of $4 \mathrm{mg}$ of $\mathrm{Fe}$ was not sufficient to return $\mathrm{Hb}$ values to normal, it was more effective in improving the $\mathrm{Fe}$ status of the animals than three daily doses of $4 \mathrm{mg}$ each as determined by HRE. The HRE of this group ( $4 \mathrm{mg}$ oral once) was remarkably higher than that of three daily oral doses of $4 \mathrm{mg} \mathrm{(30v.16 \% )} \mathrm{but}$ this higher efficiency in $\mathrm{Hb}$ regeneration was not observed in the i.p. groups where a single dose of $3.2 \mathrm{mg}$ and three daily doses of $3.2 \mathrm{mg}$ resulted in HRE of 28 and $23 \%$ respectively $(P>0.05)$. These data are consistent with previous reports (Wright \& Southon, 1990; Viteri et al. 1995) and suggest that administering intermittent $\mathrm{Fe}$ doses may be more effective than daily administration in correcting $\mathrm{Fe}$ deficiency anaemia. However, no significant difference was found in the absorption efficiency of a subsequent test dose within the orally supplemented groups.

The hypothesis that intestinal mucosal Fe concentration plays a role in $\mathrm{Fe}$ absorption cannot fully explain the higher absorption from the test dose observed in the i.p. groups. On the one hand, the group that received daily i.p. supplements had significantly less mucosal ferritin and absorbed significantly more Fe than did rats provided with oral supplements. This finding alone seems to suggest that the Fe levels of the mucosal cells, as determined by mucosal ferritin, may alter their absorptive capacity. On the other hand, the same finding was not evident in the other treatments. Ferritin concentrations in groups given single oral doses of $\mathrm{Fe}$ did not differ markedly from concentrations in rats given i.p. supplements (Table 4), yet the range of absorption of the oral groups was much lower than that of the i.p. ones.

Overall, our ferritin data correlated well with the $\mathrm{Fe}$ status as assessed by liver non-haem Fe of the animals ( $r$ $0.461, P=0.002$ ). As stated earlier, there was no difference in the state of repletion between the oral and i.p. groups as indicated by $\mathrm{Hb}-\mathrm{Fe}$ gain and liver $\mathrm{Fe}$ stores. This was also reflected in terms of mucosal ferritin for regimens $2(4 \mathrm{mg}$ oral once and $3.2 \mathrm{mg}$ i.p. once) and 3 (12 mg oral once and $9.6 \mathrm{mg}$ i.p. once). Groups in regimen 1 (daily $4 \mathrm{mg}$ oral and daily $3.2 \mathrm{mg}$ i.p.) and i.p. daily and once $(9.6 \mathrm{mg})$ were the exception. For regimen 1, despite the equal repletion state between oral and i.p. groups, mucosal ferritin was found in greater amounts in the oral than in the i.p. group. It is likely that body $\mathrm{Fe}$ stores in the i.p. group were not in equilibrium with the Fe content of intestinal mucosal cells due to our choice of a short study period ( $3 \mathrm{~d}$ ). Indeed, we chose this brief supplementation period to test whether mucosal $\mathrm{Fe}$ was important in $\mathrm{Fe}$ absorption regardless of body $\mathrm{Fe}$ stores.

Fe can induce ferritin synthesis in a concentrationdependent manner (Drysdale \& Shafritz, 1975). However, mucosal ferritin was found in larger amounts in the daily group $(4 \mathrm{mg} / \mathrm{d}$ for $3 \mathrm{~d}$ ) compared with the single-dose group receiving the same quantity of total $\mathrm{Fe}(12 \mathrm{mg})$. This was probably due to the shedding of the cells exposed to supplemental $\mathrm{Fe}$ on day 1 at the end of their $2 \mathrm{~d}$ life span. For the i.p. groups ( $3.2 \mathrm{mg}$ daily and $9.6 \mathrm{mg}$ once), it is interesting that, while they were equally repleted, more mucosal ferritin accumulated in the group given a single $9.6 \mathrm{mg}$ dose than the other group. Indeed, the intermittent group $(9.6 \mathrm{mg}$ once) received the injection $3 \mathrm{~d}$ before the measurement of ferritin in the cells but the daily group ( $3.2 \mathrm{mg}$ daily) received the last injection less than $24 \mathrm{~h}$ before the tissues were collected. Since Wood et al. (1968) demonstrated that liver is the site of primary plasma clearance of the Fe-dextran complex and that this complex clears plasma with a $t_{1 / 2}$ of $2.5-3 \mathrm{~d}$, it is likely that by the time our animals were killed only the $\mathrm{Fe}$ doses injected on day 1 , and possibly those on day 2 , have had the chance to reach the mucosal cells. This would explain the similar ferritin values found in groups 4 ( $3.2 \mathrm{mg}$ i.p. daily) and 5 ( $3.2 \mathrm{mg}$ i.p. once). It could also explain why the i.p. daily group, while equally repleted as the oral daily group, synthesized less mucosal ferritin than their oral counterpart. Another possibility is that $\mathrm{Fe}$ from the last $2 \mathrm{~d}$ of i.p. injection in the daily group may not have been equally distributed in all epithelial cells. Conrad et al. (1964) found that when radio-Fe was administered parenterally, the cells at the base of the villi were labelled first followed by a $72 \mathrm{~h}$ lag before all cells were labelled. The mechanical vibration technique used to isolate mucosal cells in our study has been reported to yield $80-90 \%$ epithelial cells of which columnar 'tip cells' and rounded 'crypt cells' are found in approximately equal numbers (Levine \& Weintraub, 1970). Since we killed the animals on day 4 of the experiment, only $\mathrm{Fe}$ injected on day 1 would have been distributed in all epithelial cells.

A surprising finding was that absorption after the $\mathrm{Fe}$ dextran i.p. injections was as high as in the Fe-deficient unsupplemented group (control). The known inverse relationship between body $\mathrm{Fe}$ stores and $\mathrm{Fe}$ absorption (Cook et al. 1974) was not observed. A similar effect has been reported by Schümann et al. (1990) who found in Fedeficient rats that 12 and $24 \mathrm{~h}$ after intravenous $\mathrm{Fe}$ administration, liver $\mathrm{Fe}$ stores were substantially repleted while intestinal Fe transfer was still as high as in the Fedeficient state. Intestinal $\mathrm{Fe}$ transfer returned to the levels 
of an untreated control group, i.e. normal Fe status, within 48-72 h after dosing. Schümann et al. (1990) explained the lag in the adaptation of $\mathrm{Fe}$ absorption to parenterallyinduced changes in Fe stores by speculating that it could be due to the amount of time new cells take to migrate from the crypt into differentiated, functional, absorptive cells. Their speculation is based on the hypothesis that the Fe received by intestinal mucosal cells during their formation regulates their subsequent absorptive behavior (Conrad \& Crosby, 1963). However, our data do not fully support this hypothesis since the single-dose groups $(3.6 \mathrm{mg}$ once and $9.6 \mathrm{mg}$ once) had received the injection $72 \mathrm{~h}$ before the administration of the isotope yet their absorption values did not differ from the daily group which received the injection $24 \mathrm{~h}$ before dosing. Our results, as well as those from Schümann et al. (1990), indicate that liver Fe stores have no means of neural or hormonal communication with the mucosal cells in adapting Fe absorption to the state of repletion at short notice.

We observed a significant positive correlation between $\mathrm{Hb}-\mathrm{Fe}$ gain and liver stores in this experiment $(r 0.724$, $P<0.001$ ). It has been stated and accepted as fact that the sequence of events during oral treatment of $\mathrm{Fe}$ deficiency anaemia is normalization of the $\mathrm{Hb}$ value first, followed by restoration of storage Fe (Bothwell \& Finch, 1962). However, the correlation above indicates that more $\mathrm{Fe}$ was absorbed during the treatment of Fe deficiency than was utilized for $\mathrm{Hb}$ synthesis. This implies that data based on $\mathrm{Hb}$ values alone may underestimate absorption.

In summary, our results lead us to four conclusions. First, oral Fe supplements, compared with i.p., caused diminished mucosal cell $\mathrm{Fe}$ absorption efficiency implicating a mucosal block after exposure to oral Fe during the treatment of Fe deficiency. However, the finding that both oral and i.p. administrations resulted in an equal rate of amelioration of $\mathrm{Fe}$ deficiency, as indicated by $\mathrm{Hb}$ gain and liver Fe, suggests that the blocking effect is not as dramatic as currently thought in the context of the poor efficacy of daily Fe supplementation programs. Second, within the oral groups and under the conditions of this study, no significant difference in mucosal cell Fe absorption efficiency was detected. However, the higher or equal efficacy of those groups receiving a single supplemental $\mathrm{Fe}$ dose in improving Fe status compared with the group receiving daily supplements for $3 \mathrm{~d}$ seems to suggest that there must be absorptive advantages associated with the administration of oral Fe supplements on an intermittent basis. Third, rats provided with i.p. Fe supplements had higher body Fe stores than did rats in the control group (unsupplemented) but intestinal Fe absorption of the test dose was similar in both groups. The inverse relationship between body $\mathrm{Fe}$ stores and Fe absorption is absent in this case suggesting that other mechanisms must be present to signal to the cells how much $\mathrm{Fe}$ to absorb. Fourth, this study was not conclusive on the nature of the blocking effect. Our data do not fully support the hypothesis that the mucosal block is due to Fe levels in the mucosal cells as determined by mucosal ferritin independent of body Fe stores. Further studies are necessary to identify the mechanism(s) of the blocking effect on Fe absorption in order to determine the scientific basis for the better efficacy of weekly rather than daily Fe supplementation for the treatment of Fe deficiency anaemia.

\section{References}

Benito P, House W \& Miller D (1997) Influence of iron supplementation frequency on absorption efficiency and mucosal ferritin in anaemic rats. British Journal of Nutrition 78, 469-477.

Bieri JG (1980) Second report of the ad hoc committee on standards for nutritional studies. Journal of Nutrition 110, 1726.

Bieri JG, Stoewsand GS, Briggs GM, Woodard JC \& Knapka JJ (1977) Report of the American Institute of Nutrition ad hoc committee on standards for nutritional studies. Journal of Nutrition 107, 1340-1348.

Bothwell TH \& Finch CA (1962) Iron Metabolism. London, England: J \& A Churchill Ltd.

Brittin GM \& Raval D (1970) Duodenal ferritin synthesis during iron absorption in the iron-deficient rat. Journal of Laboratory and Clinical Medicine 75, 811-817.

Brittin GM \& Raval D (1971) Duodenal ferritin synthesis in ironreplete and iron-deficient rats: Response to small doses of iron. Journal of Laboratory and Clinical Medicine 77, 54-58.

Brown EB, Dubach R \& Moore CV (1958) Studies in iron transportation and metabolism. XI. Critical analysis of mucosal block by large doses of inorganic iron in human subjects. Journal of Laboratory and Clinical Medicine 52, 335-355.

Conrad ME \& Crosby WH (1963) Intestinal mucosal mechanisms controlling iron absorption. Blood 22, 406-415.

Conrad ME, Weintraub LR \& Crosby WH (1964) The role of the intestine in iron kinetics. Journal of Clinical Investigation $\mathbf{4 3}$, 963-974.

Cook JD, Lipschitz DA, Miles LEM \& Finch CA (1974) Serum ferritin as a measure of iron stores in normal subjects. American Joumal of Clinical Nutrition 27, 681-687.

Crosby WH (1963) The control of iron balance by the intestinal mucosa. Blood 22, 441-449.

Drysdale JW \& Shafritz DA (1975) Induction of ferritin by iron. In Proteins of Iron Storage and Transport in Biochemistry and Medicine, pp. 319-326 [RR Crichton, editor]. Amsterdam, The Netherlands: North-Holland Publishing Company.

Granick S (1946) Ferritin. IX. Increase of the protein apoferritin in the gastrointestinal mucosa as a direct response to iron feeding. The function of ferritin in the regulation of iron absorption. Journal of Biological Chemistry 164, 737-746.

Hahn PF, Bale WF, Ross JF, Balfour WM \& Whipple GH (1943) Radioactive iron absorption by the gastrointestinal tract: Influence of anemia, anoxia, and antecedent feeding. Journal of Experimental Medicine 78, 169-188.

Hahn PF, Carothers EL, Darby WJ, Martin M, Sheppard CW, Cannon RO, Beam AS, Densen PM, Peterson JC \& McClellan GS (1951) Iron metabolism in human pregnancy as studied by radioactive isotope, ${ }^{59} \mathrm{Fe}$. American Journal of Obstetrics and Gynecology 61, 477-486.

Levine PH \& Weintraub LR (1970) Preparation of suspensions of small bowel mucosal epithelial cells. Journal of Laboratory and Clinical Medicine 75, 1026-1029.

McCurdy PR (1965) Oral and parenteral iron therapy. Journal of the American Medical Association 191, 859-862.

Momtazi S \& Herbert V (1973) Intestinal absorption using vibration-obtained individual small bowel epithelial cells of the rat: Folate absorption. American Journal of Clinical Nutrition 26, 23-29.

National Committee for Clinical Laboratory Standards (1984). Reference Procedure for the Quantitative Determination of 
Hemoglobin in Blood; Approved Standard. Villanova, PA, USA: National Committee for Clinical Laboratory Standards.

Norrby A \& Sölvell L (1974) Iron absorption and haemoglobin regeneration in posthaemorrhagic anaemia - Studies on the absorption pattern during oral iron therapy. Scandinavian Journal of Haematology 20, Suppl., 75-125.

O'Neil-Cutting MA \& Crosby WH (1987) Blocking of iron absorption by a preliminary oral dose of iron. Archives of Internal Medicine 147, 489-491.

Pritchard JA (1961) The response to iron in iron deficiency. Journal of the American Medical Association 175, 478-482.

Savin MA \& Cook JD (1978) Iron transport by isolated rat intestinal mucosal cells. Gastroenterology 75, 688-694.

Schultink W, Gross R, Gliwitzki M, Karyadi D \& Matulessi P (1995) Effect of daily vs twice weekly iron supplementation in Indonesian preschool children with low iron status. American Journal of Clinical Nutrition 61, 111-115.

Schümann K, Elsenhans B, Ehtechami C \& Forth W (1990) Increased intestinal iron absorption in rats with normal hepatic iron stores. Kinetic aspects of the adaptive response to parenteral iron repletion in dietary iron deficiency. Biochimica et Biophysica Acta 1033, 277-281.

Snedecor GW \& Cochran WG (1989) Statistical Methods. Ames, IA, USA: Iowa State University Press.

Solomons NW, Pineda O, Viteri F \& Sandstead HH (1983) Studies on the bioavailability of zinc in humans: Mechanism of the intestinal interaction of nonheme iron and zinc. Joumal of Nutrition 113, 337-349.
Torrance JD \& Bothwell TH (1968) A simple technique for measuring storage iron concentrations in formalinised liver samples. South African Journal of Medical Sciences 33, 9-11.

Viteri FE (1996) Weekly compared with daily iron supplementation. American Journal of Clinical Nutrition 63, 610 614.

Viteri FE, Liu X, Tolomei K \& Martin A (1995) True absorption and retention of supplemental iron is more efficient when iron is administered every three days rather than daily to iron-normal and iron-deficient rats. Journal of Nutrition 125, 82-91.

Welch RM \& House WA (1980) Absorption of radiocadmium and radioselenium by rats fed intrinsically and extrinsically labeled lettuce leaves. Nutrition Reports International 21, 135-145.

Wheby MS \& Crosby WH (1963) The gastrointestinal tract and iron absorption. Blood 22, 416-428.

Whittaker P, Skikne BS, Covell AM, Flowers C, Cooke A, Lynch SR \& Cook JD (1989) Duodenal iron proteins in idiopathic hemochromatosis. Journal of Clinical Investigation 83, 261267.

Wood JK, Milner PFA \& Pathak UN (1968) The metabolism of iron-dextran given as a total-dose infusion to iron deficient Jamaican subjects. British Journal of Haematology 14, 119129.

Wright AJA \& Southon S (1990) The effectiveness of various iron-supplementation regimens in improving the Fe status of anaemic rats. British Joumal of Nutrition 63, 579-585. 